IZA DP No. 9699

Life-Cycle Educational Choices:

Evidence for Two German Cohorts

Martin Biewen

Madalina Tapalaga

February 2016

Forschungsinstitut

zur Zukunft der Arbeit

Institute for the Study

of Labor 


\title{
Life-Cycle Educational Choices: Evidence for Two German Cohorts
}

\author{
Martin Biewen \\ University of Tübingen and IZA \\ Madalina Tapalaga \\ University of Tübingen, LEAD Graduate School
}

Discussion Paper No. 9699

February 2016

\author{
IZA \\ P.O. Box 7240 \\ 53072 Bonn \\ Germany \\ Phone: +49-228-3894-0 \\ Fax: +49-228-3894-180 \\ E-mail: iza@iza.org
}

\begin{abstract}
Any opinions expressed here are those of the author(s) and not those of IZA. Research published in this series may include views on policy, but the institute itself takes no institutional policy positions. The IZA research network is committed to the IZA Guiding Principles of Research Integrity.

The Institute for the Study of Labor (IZA) in Bonn is a local and virtual international research center and a place of communication between science, politics and business. IZA is an independent nonprofit organization supported by Deutsche Post Foundation. The center is associated with the University of Bonn and offers a stimulating research environment through its international network, workshops and conferences, data service, project support, research visits and doctoral program. IZA engages in (i) original and internationally competitive research in all fields of labor economics, (ii) development of policy concepts, and (iii) dissemination of research results and concepts to the interested public.
\end{abstract}

IZA Discussion Papers often represent preliminary work and are circulated to encourage discussion. Citation of such a paper should account for its provisional character. A revised version may be available directly from the author. 


\title{
ABSTRACT \\ Life-Cycle Educational Choices: Evidence for Two German Cohorts ${ }^{1}$
}

\begin{abstract}
We study life-cycle educational transitions in an education system characterized by early tracking and institutionalized branches of academic and vocational training but with the possibility to revise earlier decisions at later stages. Our model covers all major transitions ranging from preschool education through primary and secondary schooling to different forms of tertiary education and vocational training. We consider the role of previous decisions and background characteristics at each decision node and also study 'indirect' routes through the system. Our results suggest that the option to revise earlier decisions is even more socially selective than the earlier track choices that are revised later. We also model unobserved heterogeneity and document the sorting of individuals along unobserved characteristics across the stages of the system.
\end{abstract}

JEL Classification: $\quad$ 12, C5

Keywords: educational decisions, tracking, life-cycle, vocational training, non-standard transitions

Corresponding author:

Martin Biewen

School of Business and Economics

University of Tübingen

Mohlstr. 36

72074 Tübingen

Germany

E-mail: martin.biewen@uni-tuebingen.de

\footnotetext{
${ }^{1}$ We would like to thank Aderonke Osikominu, Nicole Tieben, Benjamin Nagengast, Steffen Hillmert, Stefanie Hirsch, Trudie Schils, Joachim Grammig as well as seminar participants at the University of Hohenheim and at the LEAD retreat 2015 in Bad Urach for many helpful comments and discussions. This paper uses data from the National Educational Panel Study (NEPS): Starting Cohort 6 - Adults, doi:10.5157/NEPS:SC6:3.0.1. From 2008 to 2013, NEPS data were collected as part of the Framework Programme for the Promotion of Empirical Educational Research funded by the German Federal Ministry of Education and Research (BMBF). As of 2014, the NEPS survey is carried out by the Leibniz Institute for Educational Trajectories (LIfBi) at the University of Bamberg in cooperation with a nationwide network.
} 


\section{Introduction}

Educational qualifications are a major determinant of labour market success and therefore an important source of economic and social inequalities. Most education systems around the world have a complex structure with multiple stages and differentiated tracks. In order to understand how final educational qualifications are formed, it is necessary to follow individuals through the system and examine their decisions at each branching point. As shown by Cameron and Heckman $(1998,2001)$, the sequential nature of educational decisions makes it necessary to consider all transitions in a joint way as focussing on achieved educational levels or individual transitions ignores the way how a given educational level is achieved and how background characteristics influenced prior decisions leading to this level. The aim of this paper is to study sequential transitions in the German education system. The German system is of particular interest as it provides institutionalized branches of vocational and academic training combined with early school tracking, but also combined with the possibility to switch tracks at many points and to take indirect routes to particular educational outcomes. As will be seen below, a substantial proportion of individuals takes such indirect routes through the system. The goal of this study is to examine in detail the role individual and background characteristics as well as previous decisions play at each decision node in order to establish which economic and social characteristics matter at what stage and how social selectivity differs in different parts of the system. We consider all stages of the system ranging from pre-school education through primary and secondary schooling to different forms of tertiary education and vocational training.

Our study supplements and extends the existing literature on the intergenerational transmission of educational levels (see, e.g., Shavit and Blossfeld, 1993, Müller and Shavit, 1998, Breen et al., 2009) as well as the research on individual transitions for the special case of the German system (Dustmann, 2004, Riphahn, 2003, 2005, Kristen and Granato, 2007, Educational Report, 2008, Kristen et al., 2008, Heineck and Riphahn, 2009, Luthra, 2010, Riphahn and Schieferdecker, 2012, Steiner and Wrohlich, 2012, Hillmert and Wessling, 2014, Dustmann et al., 2014). Research on educational transitions in Germany has so far mostly focussed on individual transitions at different branching points in the system. For example, Dustmann (2004) studies secondary school choice and its connection to subsequent wages. Dustmann et al. (2014) follow a similar goal using quasi-experimental variation in secondary school choice. Heineck and Riphahn (2009) examine secondary school attainment and its relation to parental background for a wide range of birth 
cohorts. Riphahn and Schieferdecker (2012) and Steiner and Wrohlich (2012) investigate the determinants of entry into tertiary education after successful completion of the highest secondary track. Riphahn (2003, 2005), Kristen and Granato (2007) and Luthra (2010) study secondary track choice with a particular focus on the potential influence of migration background. Kristen et al. (2008) do the same but for the decision to enter tertiary education. Hillmert and Wessling (2014) consider the transition from secondary school to vocational training, while Educational Report (2008) summarizes evidence on individual transitions at different stages of the system.

We do not know of many studies for the German case that consider more than one educational transition at the same time. To our best knowledge, Lauer (2003) is the only study that explicitly combines more than one stage in a two-stage ordered choice model that compares secondary and post-secondary education choices in Germany and France. Riphahn and Schieferdecker (2012) implicitly consider two stages by including a sample selection equation for successful completion of the highest secondary track in their choice model for tertiary education. We do not know of any attempts to model longer transition sequences for the German case, although such studies exist for some other countries. In their seminal contributions, Cameron and Heckman (1998, 2001) investigate sequences of educational transitions in the US system. They emphasize the importance of modeling the influence of background characteristics at each stage separately and point out the possibility of dynamic selection bias. Dynamic selection bias arises if the selective continuation of individuals in different branches of the system changes the distribution of unobserved characteristics across the different decision nodes. Despite its usefulness, the methodology of Cameron and Heckman $(1998,2001)$ has not found its way into the mainstream of transitions research. The few contributions using their methodology we are aware of include Colding (2006) and Karlson (2011) using Danish data.

Our study aims to make the following contributions. To our best knowledge it is the first one to present a complete model of all the major transitions in the German education system, including transitions that have not or that have rarely been studied before such as the decision to obtain a degree as a master craftsman after successful completion of a vocational training degree or the decision to study at a university as opposed to a more practically oriented university of applied sciences (Fachhochschule). A second contribution is that we use for our analysis of life-cycle educational decisions a data set that has become available only recently and that, to our best knowledge, has not been used for this purpose before. Our evidence based on the Starting Cohort 6 of the National Educational Panel Study (NEPS) therefore complements existing evidence on 
individual transitions obtained from other sources such as the German Socio-Economic Panel (SOEP) or the Mikrozensus. A third contribution is that, apart from modeling the main routes through the system, we explicitly consider 'non-standard' transitions such as the switching of tracks or the decision to enter tertiary education after successful completion of the practically oriented vocational training. Our analysis of 'non-standard' transitions is to a certain extent inspired by Hillmert and Jacob (2010) who also consider such transitions, using another data set and not modeling decisions in a multivariate way. We model in detail decisions between tracks but also the likelihood of finishing a given track once it has been started. Given the structure of the German system, our decision tree is more complex and much more 'non-linear' than the one considered e.g. by Cameron and Heckman (2001), Colding (2006) and Karlson (2011). A fourth contribution of our study is that we explicitly model the role of unobserved heterogeneity at each decision node and that we trace the distribution of unobserved heterogeneity through the decision nodes of the system in order to document the sorting of individuals in terms of unobserved heterogeneity. A fifth and final contribution is that we conduct our analysis separately for a cohort born between 1950 and 1964, and a cohort born between 1965 and 1979. This allows us to assess long-term changes in transition behaviour in a period of educational expansion, complementing the evidence on such changes provided in Riphahn (2003), Heineck and Riphahn (2009) and Schieferdecker and Riphahn (2012).

The rest of our paper is organized as follows. Section 2 provides an overview of the institutional details of the German education system. In section 3, we outline the econometric model used for our empirical analysis. In section 4, we describe in detail the data set on which we base our analysis. In section 5, we present and discuss our empirical results. Section 6 concludes.

\section{Overview of the German education system}

Germany has a standardized education system which is at the responsibility of each federal state. Although there are certain differences across federal states, the general structure of the system is quite uniform across the whole country. Figure 1 provides an overview of the many different possible ways through the system. ${ }^{2}$ Education generally starts with the non-compulsory Kinder-

\footnotetext{
${ }^{2}$ The numbers in the graph display the percentage of individuals in our data who pass through a given branch (upper numbers: birth cohort 1950 - 1964, lower numbers: birth cohort 1965 - 1979). See section 4 for more
} 
garten at around three. At around six years, all children enter the compulsory elementary school (Grundschule) which typically lasts four years until the age of 10. At the end of elementary school, one of three secondary tracks has to be chosen. The lowest secondary track (Hauptschule, taking five years) as well as the middle secondary track (Realschule, taking six years) typically prepare for a subsequent vocational training. The highest secondary track, Gymnasium, is academically oriented and takes nine years. Its final degree, the Abitur, is the precondition for entering tertiary education at universities or at universities of applied sciences (Fachhochschule/FH). The tracking into the three different school forms is generally by ability, although there are differences between the federal states as to whether teachers' recommendations on which track a child should choose may be overridden by parents.

The early tracking in the German school system has been a reason for concern because it is unclear whether the system is able to allocate students according to their life-time abilities and whether tracking at this early age is excessively influenced by parental background. ${ }^{3}$ However, as will be seen below, there are a number of possibilities to switch tracks. For example, graduates of Hauptschule may relatively easily obtain a Realschule degree by successfully continuing their education at a Realschule or another institution granting the Realschule degree. Although harder, graduates of Realschule may also continue their education at a Gymnasium or another institution that grants the Abitur, which will enable them to take up studies at a university or a Fachhochschule. Students may also downgrade to a lower track at any time. ${ }^{4}$

After secondary school, individuals may either complete a vocational training program, which may comprise classes at a vocational school in addition to training received from an employer, or enter tertiary education. The tertiary education sector consists of two main branches: universities and universities of applied sciences (Fachhochschulen). Degrees at universities are more academically oriented and take slightly longer than those at the more practically oriented universities of applied sciences. Of course, individuals holding the university entrance qualification (Abitur) may also first complete a vocational training program and continue with a study program at a university details.

${ }^{3}$ See, e.g., the discussion in Dustmann, 2004, Hanushek and Wössmann, 2006, Mühlenweg and Puhani, 2010, and Dustmann et al., 2014.

${ }^{4}$ In addition to the three secondary school types, so-called comprehensive schools (Gesamtschulen) were introduced from the end of the 1960s onwards. These schools either had an internal tracking system similar to the general one, or had no tracking system at all. See section 4 for how these schools are treated in our analysis. 
or a university of applied sciences at a later point of time. Individuals who have successfully completed a vocational training degree and who have some minimum amount of work experience, may obtain the degree of a master craftsman (Meister) by taking additional examinations. The master craftsman degree typically qualifies its holder to start their own business or to work as a team leader in industry or commerce.

It is important to note that education in Germany is generally free at all stages. Neither schools nor universities charged fees during the periods considered by us. Vocational training is generally provided by firms in combination with classes at state-financed vocational schools which also do not charge tuition fees. Training at firms is also free. Apprentices may even earn a wage or a salary which is however lower than that of regular employees. Given that universities and universities of applied sciences do not charge tuition fees, the cost of studying at these institutions mainly consists of subsistence expenses and the opportunity cost of not being able to work fulltime during the study program. For individuals whose parents do not have sufficient means to support their children during their studies at universities or universities of applied sciences, a student allowance (BAföG) covering subsistence costs was introduced in 1971. This allowance was gradually transformed into a (substantially) subsidized student loan in later years.

\section{Econometric Model}

In order to investigate which characteristics matter at which stage in the system, we follow Cameron and Heckman (1998, 2001), Colding (2006), Karlson (2011), and model the sequence of individual educational decisions as a function of individual characteristics and previous choices, taking account of unobserved heterogeneity. As shown by Cameron and Heckman $(1998,2001)$, the latter is potentially important as dynamic selection bias may confound the estimates of the effects of background characteristics on individual transitions. This will be the case if individuals with poor background characteristics only progress to higher stages if they have good unobserved characteristics. For example, it is plausible that individuals from poor backgrounds who progress 'against the odds' to higher stages have above average levels of motivation, ambition or ability, generating a correlation of these characteristics with background characteristics at higher stages.

Let $J$ be the set of all nodes at which an individual can make an educational transition (see figure 
1). At node $j \in J$, the individual may choose an option $c^{\prime} \in C_{j}$, where $C_{j}$ is the set of all options at $j$ (the branches originating at a particular node in figure 1 ). A model for the probability that the individual chooses option $c^{\prime} \in C_{j}$ conditional on her individual characteristics $X_{j}$ at node $j$, and conditional on unobserved heterogeneity $\eta$, is given by

$$
\operatorname{Pr}\left(D_{j, c^{\prime}}=1 \mid X_{j}, \eta\right)=\frac{\exp \left(X_{j, c^{\prime}}^{\prime} \beta_{j, c^{\prime}}+\alpha_{j, c^{\prime}} \eta\right)}{\sum_{c \in C_{j}} \exp \left(X_{j, c}^{\prime} \beta_{j, c}+\alpha_{j, c} \eta\right)}
$$

where $D_{j, c^{\prime}}$ is a dummy indicating the choice of option $c^{\prime}$ at node $j$. The individual's characteristics $X_{j}$ at node $j$ are assumed to also include the choices made at previous nodes. The parameters $\alpha_{j, c^{\prime}}$ capture the influence of unobserved heterogeneity $\eta$ on the decision for option $c^{\prime}$ at node $j$. Unobserved heterogeneity $\eta$ stands for unobserved characteristics such as unobserved aspirations, preferences or abilities which influence the choice at node $j$ in addition to the observed characteristics. The introduction of the random effect $\eta$ not only controls for dynamic selection bias but also relaxes the assumption of independence of irrelevant alternatives if $C_{j}$ contains more than two alternatives (Karlson, 2011). In order to identify all $\alpha_{j, c^{\prime}}$, the variance of $\eta$ has to be normalized. We assume $\eta$ to be normally distributed with mean zero and variance one. As common in multinomial logit models, the coefficients $\beta_{j, c}$ of one $c \in C_{j}$ are set to zero.

A possible interpretation of model $(1)$ is that the option $c_{j}^{*}$ chosen by the individual at node $j$ is the optimal choice for the individual given the situation at $j$, i.e.

$$
c_{j}^{*}=\arg \max _{c \in C_{j}} V_{j, c},
$$

where $V_{j, c}=X_{j, c}^{\prime} \beta_{j, c}+\alpha_{j, c} \eta+\nu_{j, c}$ is the value of option $c \in C_{j}$ with $\nu_{j, c}$ coming from an extreme value distribution independently across $c \in C_{j}$ (Cameron and Heckman, 2001). In an alternative interpretation, equation (1) simply describes other behavioral mechanisms that link the choice at $j$ to observed and unobserved characteristics $X_{j}$ and $\eta$.

Given the sequential structure of decisions $D=\left\{D_{j, c}, j \in J, c \in C_{j}\right\}$, the probability of observing the sequence of choices made by the individual conditional on observed information $X=\left\{X_{j}, j \in J\right\}$ can be written as

$$
L(D \mid X, \theta)=\int_{\eta} \prod_{j \in J}\left[\prod_{c^{\prime} \in C_{j}} \operatorname{Pr}\left(D_{j, c^{\prime}}=1 \mid X_{j}, \eta\right)^{D_{j}, c^{\prime}}\right] \phi(\eta) d \eta,
$$

where $\theta$ collects all the parameters of the model. 
For certain purposes, our interest lies in predicting the value of the unobserved heterogeneity term $\eta$ for an individual with observed characteristics $X=\left\{X_{j}, j \in J\right\}$ which we compute as the posterior prediction

$$
\hat{\eta}=\int_{u} u \omega(u \mid D, X, \hat{\theta}) d u
$$

using the empirical conditional posterior distribution

$$
\omega(u \mid D, X, \hat{\theta})=\frac{\operatorname{Pr}(D \mid X, u, \hat{\theta})}{\int_{u^{\prime}} \operatorname{Pr}\left(D \mid X, u^{\prime}, \hat{\theta}\right) \phi\left(u^{\prime}\right) d u^{\prime}}
$$

after inserting the maximum likelihood estimates $\hat{\theta}$ for $\theta$ based on (3) (see Rabe-Hesketh et al., 2004).

For the presentation of our results, we compute average partial effects of changing certain variables in $X_{j}$ on the probability to choose a particular option $c^{\prime}$ at node $j$. For these partial effects, we calculate for each individual the discrete probability change given $X_{j}$ and $\hat{\eta}$ and average these probability changes over all individuals who take a decision at node $j$. In order to compute standard errors for the average partial effects, we employ a parametric bootstrap procedure resampling from the full joint distribution of $\hat{\theta}$ and repeating the calculation of the average partial effects 1000 times (similar to Cameron and Heckman, 2001).

\section{Data and descriptive statistics}

Our empirical analysis is based on rich retrospective life-cycle data from the National Educational Panel Study (NEPS, starting cohort adults, SC6). ${ }^{5}$ The data set contains extensive retrospective information about family background, education, employment and other life domains for 11,932 individuals born between 1944 and 1986. In our analysis, we focus on two cohorts of individuals born between 1950 and 1964 (cohort 1) and between 1965 and 1979 (cohort 2). The reason to exclude individuals born earlier or later is that schooling histories immediately after the war were often irregular and that individuals born after 1980 were in many cases too young to have fully completed their education when the survey was carried out in 2007/08. We include in our analysis only individuals with at least one secondary school spell in West Germany, as transitions in the East German school system under socialism differed in many ways from those in the larger, western part of the country.

\footnotetext{
${ }^{5}$ See Blossfeld et al. (2011).
} 
An overview of the percentages of individuals per cohort who passed through the different nodes of the system is given in figure 1 (upper numbers: cohort 1 , lower numbers: cohort 2). In order to keep the tree reasonably simple, we made a number of simplifications when extracting the transitions from our data. We only considered changes between the three secondary tracks which took place after grade seven (i.e. we regard track changes before that as reflecting a wrong placement in the first place). We observe a small number of individuals in comprehensive schools (Gesamtschule and Waldorfschule) which we group into the respective track if the school had an internal tracking system. If this is not the case, we group these individuals into the middle track. We also observe a small number of individuals in schools for individuals with disabilities (Sonderschule or Förderschule) which we group into the lower secondary track. In all of these cases, we explicitly control for these characteristics when modeling transition probabilities. ${ }^{6}$

Looking at the descriptive statistics shown in figure 1 , the most conspicuous differences between the two cohorts are the higher share of individuals in cohort two who pass through Kindergarten, a general shift from the lower secondary track (Hauptschule) to the middle secondary track (Realschule) and to the upper secondary track (Gymnasium), and a moderately higher share of individuals who take up studies at universities or universities of applied sciences. Another remarkable difference is higher share of individuals who upgrade to Gymnasium from the lower secondary track Realschule. The percentages at the remaining nodes are remarkably stable across the two cohorts, including the percentages of individuals who drop out of individual tracks.

As described above, our goal is to model the decisions at each branching point in the system as a function of individual and background characteristics, and of previous decisions. The list of characteristics considered by us is given in table 1 . With regard to parents' education we distinguish between the four different categories shown in table 1. For parents' occupational status we form three groups: high (managers, high ranking civil servants and military personnel, doctors, highly qualified white collar workers, self-employed with at least ten employees), medium (qualified white collar workers, master craftsmen, middle ranking civil servants and military personnel, selfemployed with less than ten employees), and low (all others). Initial experiments with including fathers' and mothers' educational and occupational background separately did not yield additional insights so that we only included parents' maximal status in our final specifications. As further

\footnotetext{
${ }^{6}$ Also note that individuals who initially left Hauptschule, Sonderschule or Förderschule without a degree may obtain the Hauptschule degree later, e.g. at a vocational school. This explains the low proportion of individuals without school degrees.
} 
characteristics we considered the number of siblings, whether the person grew up with only one parent up to the age of 15 (= broken family), gender, and migration status (one of the following holds: not born in Germany, at least one parent not born in Germany, no German citizenship, mother tongue not German, there exists a second mother tongue). We also include (self-reported) information on parents' expectations with respect to learning and having a career ('How important is it for your parents that you always learn something new?' / How important is it for your parents that you have a very successful career?') which proxy for educational aspirations.

Apart from our main explanatory variables, we include a number of control variables in our decision models at each node. These include information on previous transitions such as whether the person went to Kindergarten, whether she switched secondary school tracks (upwards or downwards), from which secondary school track and school type she eventually graduated (Hauptschule, Realschule, Gymnasium, Sonder-/Förderschule, Gesamtschule), whether she dropped out of previous educational tracks or whether she completed a vocational training degree before deciding to take up studies at a university or a university of applied sciences. The idea to include information on previous transitions is to measure the influence of background characteristics at each node net of their influence at preceding nodes. We also include individual indicators of ability (based on grade point averages in secondary school and past retentions), regional dummies ${ }^{7}$, a regional labor market indicator (the deviation of the unemployment rate from a local polynomial trend at the level of the federal states) as well as a quadratic time trend.

In order to improve identification, we make use of 'node instruments' which shift decisions at some nodes but not at others. Motivated by Mühlenweg and Puhani (2010) and Dustmann et al. (2014), we include at the end of elementary school (Grundschule) a dummy indicating whether the person was born before the school year cutoff date. The idea is that individuals who were born before the school year cutoff date are comparatively young when enrolling in elementary school and that this age disadvantage may make them marginally less likely to choose the more advanced secondary school tracks after grade four. We also include at the Grundschule node the population share of students (at grade seven and at the level of the federal state) who attend Hauptschule, Realschule or Gymnasium. Similarly, we include the federal ratio of students to population aged 20 to 22 years at the Realschule degree, the Gymnasium degree, and the Vocational training degree nodes to pick up aggregate trends of enrolling in tertiary education.

\footnotetext{
${ }^{7}$ Unfortunately, given the number of observations, it was not possible to include dummies for each federal state. Instead, we formed four regions: North, West, Middle, and South Germany.
} 
For our estimations, we had to omit some of the nodes shown in figure 1 due to the relatively small number of individuals who passed through them. In particular, we omitted Hauptschule, Hauptschule dropout, Realschule dropout, and Gymnasium dropout. We experimented with including as many nodes and branches in our model as possible but found that including some of the nodes with few observations led to convergence problems or problems of perfect prediction. We also combined graduating from University or Fachhochschule into one node. This means that the individual first chooses at the Study node between enrolling at a University or a Fachhochschule, but then the probability of successfully completing the study program is modeled jointly for both groups of students, controlling for the track the individual is enrolled in. Similarly, we combined the two groups of students when modeling whether a person goes back to vocational training after dropping out of tertiary education.

\section{Empirical Results}

In this section we present and discuss our empirical results on how different characteristics are related to the decisions at the different stages of the system. The results are presented in terms of average partial effects of changing our main covariates on the probability of choosing a particular alternative at a given node. ${ }^{8}$

\subsection{Parental education}

Parental education is a key regressor in the analysis of educational transitions as it most directly describes the intergenerational transmission of educational status and thus the social selectivity of educational qualifications. Our results for parental education are given in table 2. For example, the estimates suggest that in cohort two, the likelihood of taking part in early education in Kindergarten was - holding other observed characteristics constant - 13.7 percentage points higher for children from parents with tertiary education than for children from the reference group of parents in the lowest educational group (see table 1 for the definition of educational groups). Similarly, it was 12.9 percentage points higher for children from parents with Abitur (but no ter-

\footnotetext{
${ }^{8}$ We refrain from reporting estimates of the underlying coefficients as our full model includes (per cohort) 365 estimated parameters at 15 decision nodes. Detailed results are available on request.
} 
tiary education), and about 7.9 percentage points higher for parents with vocational training but no Abitur. The cohort comparison suggests that, while going to Kindergarten was to a certain extent selective in cohort two, it used to be more selective in cohort one in which only parents from the highest educational group were more likely to send their children to Kindergarten. Given the evidence on early skill formation (Cunha and Heckman, 2007), the selectivity of Kindergarten attendance is potentially important for further educational transitions. However, including prior Kindergarten attendance as a regressor in subsequent transitions, we only found small and statistically insignificant effects of having attended Kindergarten on these further transitions.

The decision for one of the secondary school tracks after elementary school is a major branching point in the German school system as it preselects individuals for the subsequent academic and non-academic tracks. The results confirm the high selectivity of this transition with respect to parents' educational background. The likelihood of choosing the lowest track Hauptschule was the lower the higher the educational background of the parents, while the likelihood of opting for the highest track Gymnasium drastically increased in the educational level achieved by parents. This pattern was quite stable across the two cohorts, except for a negative partial effect of parents having tertiary education on the likelihood of enrolling into the middle track Realschule that emerges in cohort two. This suggests that the general educational upgrading in secondary school did not reduce social selectivity but even increased it in the sense that children from the highest educational background were even more exclusively selected into the highest secondary track. This is consistent with findings presented in Heineck and Riphahn (2009) based on an alternative data set (the Mikrozensus).

A clear pattern that emerges from table 2 is that while the selection into tracks depended to a great extent on parents' educational background, the likelihood of completing a track once it had been chosen was independent of parental background. In particular, the likelihood of finishing Realschule with a degree conditional on having started this track was not significantly related to parents' educational background, and the same is true for Gymnasium. By contrast, the likelihood of switching to a higher track track was highly selective. The probability of upgrading from Hauptschule to the middle track Realschule was substantially increased if one of the parents had a tertiary education degree. Similarly, the probability of upgrading from the middle track to the highest track Gymnasium was much higher for individuals with parents who had either a tertiary education degree or Abitur. This shows that the option to revise educational decisions was not much used by those whose educational background may have held them back earlier, but 
by those from higher backgrounds who seized the 'second chance' to preserve the status achieved by their parents. The selectivity of upgrading decisions became stronger in cohort two, although the hypothesis that coefficients are equal across cohorts cannot be rejected statistically.

While for individuals choosing the vocational track after school we do not find any significant effects of parents' education on further transitions, we do find such effects for decisions on the academic track. Once the decision to take up studies had been taken, individuals from lower educational backgrounds were much more likely to choose the more practically oriented (and somewhat lower ranking) universities of applied sciences (Fachhochschulen) than the academically oriented universities. Moreover, among individuals who dropped out of university or Fachhochschule, those whose parents had a vocational training degree were more likely to start vocational training themselves, pointing to a persistence of occupational decisions across cohorts. Again, there are no effects of parental educational background on finishing vocational training, on finishing a university or Fachhochschule degree, or on finishing a master craftsman degree, conditional on having started these tracks.

\subsection{Parents' occupational status}

Parents' occupational status is another key regressor of educational transitions. First, we expect parents' highest occupational status to be substantially correlated with family income so that some of the following results should be interpreted in this way. ${ }^{9}$ Second, there may be a direct influence of parents' occupations on children's educational decisions in the sense that children follow similar occupational paths as their parents because of preferences formed during childhood or because of a higher familiarity with the occupational possibilities in the field chosen by their parents. We expect the first reason to be particularly relevant in situations where costs of an educational decision play a role, while the second reason should be independent of costs.

The first row of table 3 shows the effects of parents' occupational status on the probability of attending Kindergarten. Recall that the results shown are ceteris paribus effects, i.e. even holding constant parents' educational background (and all the other characteristics shown in table 1), coming from a family with higher occupational status was associated with a significantly higher probability of attending Kindergarten. Possible explanations for this pattern are that sending

\footnotetext{
${ }^{9}$ Unfortunately, we lack a more direct indicator of parental income in our NEPS data.
} 
children to Kindergarten involved (moderate) fees and that the division of labour in low status households tended to be more traditional, i.e. women were less likely to work. The association of parents' occupational status became slightly weaker in cohort two, suggesting that the secular rise in Kindergarten attendance made its access more egalitarian.

The decision for one of the three secondary school tracks was also highly selective in parents' occupational status. Holding parents' educational status and other characteristics constant, children whose parents' occupational status was medium or high had a lower probability of choosing the lower track, and a much higher probability of choosing the highest track. The pattern was quite stable across cohorts with a slight tendency of further differentiation at medium to higher occupational levels. Again, the probability of finishing a track once it had been chosen was not significantly influenced by parental background. However, parents' occupational background mattered for upwards track mobility. Children with higher occupational backgrounds were more likely to upgrade from Hauptschule to Realschule and from Realschule to Gymnasium, although this pattern appears to be much weakened in the second cohort. Generally, the association of upward track mobility with occupational background was also much weaker than with educational background (compare table 2). This suggests that financial constraints and direct intergenerational links between occupational status were less important for upgrading decisions than the preservation of the educational status of the parents.

It is often thought that parental backgrounds tend to loose their explanatory power at later educational stages. We do not find this to be the case. After having successfully completed vocational training, individuals whose parents had medium or high occupational status were much more likely to continue their education at university or Fachhochschule than those whose parents had low occupational status. Moreover, among all individuals who started a tertiary education degree (university or Fachhochschule), especially those from parents with high occupational status were more likely to choose to study at a university rather than at a more practically oriented Fachhochschule. This suggests an effect of parents' occupational status on children's tertiary education choices that is separate from parents' financial resources as there is essentially no difference in the cost of studying at a university or at a Fachhochschule. The results also show that, at least in cohort one, parents' higher occupational background made individuals less likely to start vocational training after dropping out of tertiary education, also pointing to a direct influence of parents' occupational choices on those of their children. Perhaps surprisingly, we 
measure no effects of parents' occupational status on taking up or finishing a master craftsman degree.

\subsection{Gender}

The partial effects of gender are displayed in table 4. Here, we observe interesting changes over cohorts. While there was only a slight and stable disadvantage for women in terms of having attended Kindergarten, the pattern of choosing secondary tracks changed fundamentally from the first to the second cohort. In the earlier cohort, females were more likely to choose the middle track Realschule and less likely to choose the highest track Gymnasium. This pattern was reversed in the later cohort in which females were less likely to choose the lower track Hauptschule, but even more likely to choose the highest track Gymnasium than their male counterparts. This shows that females benefited more from the general upgrading in secondary schooling that took place from cohort one to cohort two. However, this did not translate into a higher share of women continuing their education at university or Fachhochschule as among graduates of Gymnasium in cohort two, women were now less likely to go on to study, which was not the case in the earlier cohort.

There were also clear gender differences in 'second chance' mobility between secondary tracks. In both cohorts, women were more likely than men to upgrade from the lowest track Hauptschule to the middle track Realschule, but much less likely to upgrade from the middle track to the highest track Gymnasium. Further substantial gender differences emerge for the decisions related to vocational training. Women were generally less likely to finish a vocational training degree once they had started it, they were much less likely to pursue a master craftsman degree after vocational training, and less likely to continue their education at university or Fachhochschule after having successfully completed vocational training. This picture is consistent with the hypothesis that the generally lower labour market participation of women at the time and the more likely interruption of their educational careers through marriage and fertility episodes led to generally less favorable educational transitions when compared to men. On the other hand, once women got to the stage of starting tertiary education, we observe no gender differences with respect to studying at a university rather than at the more practically oriented Fachhochschule, with respect to completing these tracks or with respect to the behaviour after a potential dropout from tertiary education. 


\subsection{Number of siblings}

The number of siblings serves as a potentially important indicator of family background which may influence educational decisions through at least two channels. First, there may be budget constraints for educational investments within a family. These will be the more binding the more children there are to invest in. Another possible channel are peer or competition effects, i.e. individuals may be influenced by their siblings in what level of and which kind of education they pursue. The results in table 4 show that the association of the number of siblings with educational decisions was generally both moderate and relatively stable over cohorts. In both cohorts, there was a slight negative effect of the number of siblings on the probability of attending Kindergarten, which may be explained by the fact that it is easier to look after another child at home if there are already siblings to look after. Moreover, the likelihood of choosing the lowest secondary track was moderately increased by the number of siblings, while that of choosing the highest track was decreased. This might indeed reflect family budget constraints, although we cannot rule out that there is a direct connection between the number of children and preferences for higher or lower educational tracks. In addition, there was a negative association of the number of siblings with upwards track mobility, which is also consistent with budget constraints as larger families may have a harder time to finance educational tracks that take longer. At later educational stages we do not measure any effects of the number of siblings on decisions related to vocational training or on studying at university. This may be interpreted as evidence against the sibling rivalry hypothesis, which suggests that especially at higher stages individuals with siblings are under more pressure to pursue higher degrees. ${ }^{10}$

\subsection{Broken family status}

Growing up with only one parent may influence educational decisions both through financial constraints and through effects on motivation, ambition and self-confidence. Table 5 shows that we indeed measure negative effects of broken family status on a number of transitions. Keeping other things constant, the likelihood of choosing the lower secondary track was much higher for

\footnotetext{
${ }^{10}$ The only significant effect we measure at later stages is that of the number of siblings on the propensity to continue with vocational training after dropping out of tertiary education. This result and especially the sign change over cohorts is hard to explain. Note however that it is based on a relatively small number of observations.
} 
individuals in broken families, while that of choosing the highest track was much lower. This effect even increased from cohort one to cohort two. There was also a significant and substantial negative effect of broken family status on upward track mobility as well as on the likelihood of finishing a given secondary track once it had been started. However, these effects vanished in cohort two. Remarkably, broken family status was also related to a significantly lower probability of successfully finishing vocational training or a tertiary education degree once it was started. This is remarkable as the risk of not finishing a given educational track conditional on having starting it was largely independent of the other covariates considered so far. This finding demonstrates that very different characteristics may matter at different points in the educational career. Note that in cohort two, individuals from broken families also had a significantly lower propensity to continue with a master craftsman degree after having successfully completed vocational training. This points to a potentially longer lasting effect of growing up in a broken family.

\subsection{Migration status}

Our results for migration status are shown in table 5. Perhaps surprisingly, we find relatively little connection of this characteristic with educational transitions. Recall however, that we control for many other things (especially parental background) such that the remaining influence of migration status may be small or even non-existent. According to table 5, individuals with migration status even chose more favourable tracks than natives in some cases. In cohort one, they were ceteris paribus more likely to upgrade from the middle secondary track to the highest track and were less likely to stop their education after vocational training. In cohort two, individuals with migration background were significantly more likely to start tertiary education after having successfully completed Gymnasium. The only case for which we measure a migrant 'disadvantage', is that individuals with migration background were less likely to finish a Realschule degree in cohort two once they had started it.

Our result that individuals with migration background did generally not choose lower tracks but even tended to opt for higher tracks when controlling for parental background variables is in line with recent evidence presented in Kristen and Granato (2007), Kristen et. al (2008) and Luthra (2010). Based on data from the Mikrozensus, Kristen and Granato (2007) show that controlling for parental education and occupation completely eliminates differences between natives and migrants in the likelihood of holding the Abitur degree. Luthra (2010) finds that 
some ethnicities even display an 'immigrant advantage effect'. Kristen et al. (2008) show that Turkish immigrants are more likely to enter tertiary education than natives when controlling for parental characteristics. The result that immigrants choose higher tracks than natives may be explained by a lack of familiarity with the German education system or by generally higher educational aspirations originating from their home countries (see Kristen and Granato, 2007, Kristen et al., 2008, and Luthra, 2010 for more details). Riphahn (2005) finds the opposite result that educational upgrading in secondary education was smaller for immigrants, so that an immigrant disadvantage remains (note however that her parental background controls are less comprehensive than in the other studies cited and that the periods considered only partly overlap between these studies). Both Riphahn (2005) and the other studies suggest that changes in the effects of migration status across cohorts are likely to be related to the changing composition of the migrant population (earlier cohorts mostly came from Greece, Italy and Spain, while in later cohorts, Turks were the majority).

\subsection{Parental expectations}

Parental expectations are an indicator of aspirations which may have a strong influence on educational transitions. The results for the potential influence of parental expectations (only available for cohort two) on educational transitions are given in the third column of table 5 . The first question we used was one about parents' expectations about learning ('How important is it for your parents that you always learn something new?'). Here, we generally observe no significant relation to individual educational transitions, except for a negative effect of higher expectations on opting for university rather than for Fachhochschule and a negative effect on finishing a university or Fachhochschule degree conditional on having started it. ${ }^{11}$ An explanation for the latter effect could be that overly ambitious parents push their children into higher education although they are not willing or not able to complete it. For the second question 'How important is it for your parents that you have a very successful career?' we obtain a similar pattern. Children whose parents' expectations were higher were less likely to choose the middle secondary track Realschule but more likely to choose the highest track Gymnasium. They were also significantly more likely to upgrade from the middle to the highest track. However, once having reached the

\footnotetext{
${ }^{11}$ The partial probability effect refers to a change of the response to the above question from 'rather unimportant' to 'rather important'.
} 
highest track, they were less likely to successfully complete it. Again, this suggests that parents may push children into tracks for which they are not suited. Recall that the effects we measure for parental expectations are again net of the influence of other characteristics, in particular parents' educational and occupational status, i.e. they are likely to represent ceteris paribus effects of aspirations holding constant other characteristics.

\subsection{Unobserved heterogeneity}

Having controlled for the influence of a large number of observed variables, it is interesting to see to what extent unobserved person-specific factors mattered in addition for transitions. The partial probability effects of increasing the random effect term by one standard deviation on the decisions at individual nodes are given in the second and the last column of table 5 . With very few exceptions, the effects are strikingly similar across cohorts (although estimation was completely independent) suggesting a remarkably stable pattern. It turns out that unobserved heterogeneity plays some role in the decision between the lowest secondary track and the middle one in the sense that higher values of the unobserved heterogeneity term push individuals into the middle rather than into the lower track. The most substantial effects of the unobserved heterogeneity term can be observed for upward transitions between secondary school tracks. Here, the ceteris paribus effect of a one standard deviation change of the unobserved heterogeneity on the probability of upward mobility from Hauptschule to Realschule, and from Realschule to Gymnasium was around 35 percentage points in cohort one and around 20 to 25 percentage points in cohort two.

At first sight, the effect of the unobserved heterogeneity term at the Gymnasium degree node is surprising as individuals with high values ceteris paribus opt for vocational training after Gymnasium rather than choosing to study at a university or Fachhochschule. However, one has to keep in mind that there is a considerable inflow into the Gymnasium node from the lower Realschule node consisting of individuals with high values for the unobserved heterogeneity term. If these individuals are more likely to opt for vocational training after having successfully completed Gymnasium, then this will generate a negative relationship between the unobserved heterogeneity term and the transition to a tertiary education degree. A similar effect has been found by Riphahn and Schieferdecker (2012) who measure a negative correlation between the unobservables leading to Gymnasium degree and those leading to university studies. At the Vocational training degree node, the unobserved heterogeneity term again is an indicator of strong upward mobility: 
individuals with high levels of it were much more likely to start a university or a Fachhochschule degree after having finished their vocational training. Interestingly, such individuals then ceteris paribus more often chose to study at a more practically oriented Fachhochschule rather than at university, and they were less likely to finish the tertiary education degree once they started it (the latter only in cohort two).

We explore these patterns in more detail by examining how the distribution of predicted random effects (4) changes across decision nodes. Figure 2 shows this distribution for all individuals. By construction of the model, the distribution is centered, i.e. the average random effect term (as represented by the vertical bar) is zero. Going on to secondary school degrees, we find that individuals who obtain the lowest secondary degree Hauptschule tend to be negatively selected, while those going through the middle and the upper track tend to be positively selected (figures 3 to 7 ). For the upper secondary track Gymnasium, we also observe a slight tendency of the distribution to become more spread out in cohort two (figure 6). This is consistent with the hypothesis that the expansion of participants in higher secondary education led to a more heterogenous composition of the individuals studying there as also less talented and less ambitious individuals were admitted into these tracks. The distribution of unobserved heterogeneity among individuals in vocational training is not much different from that of the overall population (figures 8 and 9 ). As expected, individuals going through the Study node were on average positively selected (figure 10). However, the distribution displays a conspicuous heaping at the upper tail which turns out to be the group of highly positively selected individuals who reach the Study node indirectly via prior vocational training (see the distribution for these individuals in figure 11). The distribution for those who obtain a university or a Fachhochschule degree and that for those who drop out of these tracks resemble the distribution at the Study node, although the distribution for the dropouts has more mass at the lower end, as expected (figures 12 and 13). The distribution at the Master craftsman node is very much centered around zero, i.e. these individuals are neither positively nor negatively selected in terms of unobserved heterogeneity (figure 14).

\section{Summary and discussion}

This paper presents a comprehensive analysis of transitions in the German education system using life-cycle data from the Starting Cohort 6 of the National Educational Panel Study (NEPS). 
Our analysis covers educational transitions from Kindergarten through primary and secondary school up to vocational training, different forms of academic education and further vocational degrees. We examine the role of individual and background characteristics at each decision node taking account of previous decisions and unobserved heterogeneity. Our results confirm the high selectivity of educational transitions in Germany with respect to parental background found in other studies such as Dustmann (2004), Heineck and Riphahn (2009), Schieferdecker and Riphahn (2012). This selectivity is all the more a reason for concern as individuals are streamed into different tracks at a relatively young age. Contrary to what might be expected however, we find that social selectivity is not mitigated by the options built in the system to revise earlier decisions. On the contrary, selectivity in terms of parental background is equally high and in some cases even higher at the points where individuals may upgrade from lower to higher tracks or continue with more advanced forms of education after having completed more basic ones. This suggests that these options are not used by those whose poor background may have held them back at earlier decisions but rather by those from higher backgrounds to seize the 'second chance' to preserve the status achieved by their parents.

While it is clear that our observational data and limited range of covariates will not allow us to identify clear causal effects, our comprehensive treatment of all possible transitions provides some indications as to the relevance of different mechanisms explaining the influence of background characteristics on transitions (see, e.g., Hillmert and Jacob, 2010, for a summary of such mechanisms). We find that both parents' educational and parents' occupational status have separate effects on transitions but that those of educational status are generally stronger. A possible interpretation is that transitions are not only influenced by parental financial resources but by 'cultural' factors of 'nurture' or by the wish to preserve the relative status achieved by the parents (Boudon, 1974). This view is reinforced by the finding that parents' educational background is substantially stronger than parents' occupational status for 'second chance' transitions that aim to correct earlier decisions. The fact that education in the system studied by us is generally free is another indication that non-financial factors play some role in explaining transitions. Another relevant result is that, while the decision for certain tracks is often strongly associated with background variables, the likelihood of successfully finishing them is generally independent of such variables. Contrary to what might be expected, we find strong associations of background variables with some later transitions. Conditional on having decided to enter tertiary education, individuals from higher educational backgrounds were much more likely to study at universities 
rather than at the more practically oriented university of applied sciences. This effect is separate from and stronger than that of higher parental occupational status, again suggesting a stronger influence of 'cultural' as compared to economic transmission channels.

Our cohort comparison suggests a high degree of stability of transition patterns across the two cohorts considered by us. This is remarkable as the period under consideration was one of considerable educational expansion, see Heineck and Riphahn (2009) for a detailed discussion. Despite the general stability of transition patterns, we observe a slight intensification rather than a decrease of social selectivity from cohort one to cohort two. For example, the effects of parents' educational status on the probability of choosing the highest secondary track became stronger. Similarly, the association of parents' education with upgrading from lower to higher tracks substantially increased from cohort one to cohort two. The influence of parents belonging to the highest occupational group on choosing the highest secondary track also increased from cohort one to cohort two. A rather unfavourable trend was that the disadvantages associated with broken family status with respect to secondary school track choice and with respect to successfully completing certain tracks exacerbated from cohort one to cohort two. On the other hand, we observe a limited number of decreases in social selectivity. Kindergarten attendance became more egalitarian from cohort one to cohort two, although we cannot measure any effect of Kindergarten attendance on subsequent educational transitions. Another improvement was that the relationship between parents' occupational (not educational) status and upward track mobility was weaker in cohort two. Altogether however, we have to extend the conclusion made for secondary school attainment by Heineck and Riphahn (2009) that in spite of massive policy interventions the role of parental educational background was not reduced to all other transitions.

Finally, we analyze the role of remaining unobserved heterogeneity for transitions at particular stages of the system. We document a moderate amount of sorting along unobserved characteristics, which appears to be strongly related to non-standard upwards mobility. The effect of unobserved heterogeneity is particularly strong for the upgrading decision from the lower to the middle and from the middle to the higher secondary track as well as for the decision to enter tertiary education after initial choice of the vocational track. We observe the interesting phenomenon that individuals who unexpectedly progressed to higher tracks tended to be more modest at subsequent stages preferring less ambitious to more ambitious tracks at later stages. 


\section{References}

Blossfeld, H.-P., Roßbach, H.-G., von Maurice, J. (Eds.) (2011): Education as a lifelong process: The German National Educational Panel Study (NEPS). [Special Issue] Zeitschrift für Erziehungswissenschaft, Vol 14.

Boudon, R. (1974): Education, Opportunity, and Social Inequality - Changing Prospects in Western Society, New York: Wiley.

Breen, R., R. Luijkx, W. Müller, and R. Pollak (2009): Nonpersistent Inequality in Educational Attainment: Evidence from Eight European Countries. American Journal of Sociology, Vol. 114, pp. 1475-1521.

Cameron, S.V., J. Heckman (1998): Life Cycle Schooling and Dynamic Selection Bias: Models and Evidence for Five Cohorts of American Males. Journal of Political Economy, Vol. 106, pp. 262-333.

Cameron, S.V., J. Heckman (2001): The Dynamics of Educational Attainment for Black, Hispanic, and White Males. Journal of Political Economy, Vol. 109, pp. 455-499.

Colding, B. (2006): A dynamic analysis of educational progression of children of immigrants. Labour Economics, Vol. 13, pp. 479-492.

Cunha, F., J. Heckman (2007): The Technology of Skill Formation. American Economic Review, Vol. 97, pp. 31-47.

Dustmann, C. (2004): Parental background, secondary school choice, and wages. Oxford Economic Papers, Vol. 56, pp. 209-230.

Dustmann, C., P. Puhani, and U. Schönberg (2014): The Long-Term Effects of Early Track Choice. IZA Discussion Paper No. 7897. Institute for the Study of Labor (IZA), Bonn.

Educational Report (2008): Autorengruppe Bildungsberichterstattung im Auftrag der Ständigen Konferenz der Kultusminister der Länder in der Bundesrepublik Deutschland und des Bundesministeriums für Bildung und Forschung (ed.). Bildung in Deutschland. Ein indikatorengestützter Bericht mit einer Analyse zu Übergängen im Anschluss an den Sekundarbereich I, Bielefeld: Ber- 
telsmann, available at $h t t p: / / w w w . b i l d u n g s b e r i c h t . d e /$.

Hanushek, E.A., L. Wössmann (2006): Does Educational Tracking Affect Performance and Inequality? Differences-in-Differences Evidence Across Countries. Economic Journal, Vol. 116, pp. C363 - C376.

Heineck, G., R. Riphahn (2009): Intergenerational Transmission of Educational Attainment in Germany - The Last Five Decades. Journal of Economics and Statistics, Vol. 229, pp. 36-60.

Hillmert, S., M. Jacob (2010): Selections and social selectivity on the academic track: A lifecourse analysis of educational attainment in Germany, Research in Social Stratification and Mobility, Vol. 28, pp. 59-76.

Hillmert, S., K. Wessling (2014): Soziale Ungleichheit beim Zugang zu berufsqualifzierender Ausbildung. Sozialer Fortschritt, Vol. 63, pp. 72-82.

Karlsen, K.B. (2011): Multiple paths in educational transitions: A multinomial transition model with unobserved heterogeneity. Research in Social Stratification and Mobility, Vol. 29, p. 323341.

Kristen, C., N. Granato (2007): The educational attainment of the second generation in Germany. Social origins and ethnic inequality. Ethnicities, Vol. 7, pp. 343-366.

Kristen, C., D. Reimer, and I. Kogan (2008): Higher Education Entry of Turkish Immigrant Youth in Germany. International Journal of Comparative Sociology, Vol. 49, pp. 127-151.

Lauer, C. (2003): Family background, cohort and education: A French-German comparison based on a multivariate ordered probit model of educational attainment. Labour Economics, Vol. 10, pp. 231-251.

Luthra, R.R. (2010): Assimilation in a New Context: Educational Attainment of the Immigrant Second Generation in Germany. ISER Discussion Paper, No. 2010-21, Institute for Social and Economic Research (ISER), University of Essex.

Mühlenweg, A.M., P. Puhani (2010): The Evolution of the School-Entry Age Effect in a School Tracking System. Journal of Human Resources, Vol. 45, pp. 407 - 438. 
Müller, W., Y. Shavit (1998): Bildung und Beruf im institutionellen Kontext. Eine vergleichende Studie in 13 Ländern. Zeitschrift für Erziehungswissenschaft, Vol. 1, pp. 501-533.

Riphahn, R. (2003): Cohort effects in the educational attainment of second generation immigrants in Germany: An analysis of census data. Journal of Population Economics, Vol. 16, pp. 711-737.

Riphahn, R. (2005): Are there Diverging Time Trends in the Educational Attainment of Nationals and Second Generation Immigrants? Journal of Economics and Statistics, Vol. 225, pp. 325-346.

Riphahn, R., F. Schieferdecker (2012): The transition to tertiary education and parental background over time. Journal of Population Economics, Vol. 25, pp. 635-675.

Shavit, Y., H.P. Blossfeld (Eds.) (1993): Persistent inequality. Changing educational attainment in thirteen countries. Boulder: Westview Press.

Skrondal, A., and S. Rabe-Hesketh (2004): Generalized Latent Variable Modeling: Multilevel, Longitudinal, and Structural Equation Models. Boca Raton, FL: Chapman \& Hall/CRC.

Steiner, V., K. Wrohlich (2012): Financial Student Aid and Enrollment in Higher Education: New Evidence from Germany. Scandinavian Journal of Economics, Vol. 114, pp. 124-147. 


\section{Tables}

Table 1 - Descriptive statistics

\begin{tabular}{|c|c|c|c|c|}
\hline \multirow{2}{*}{ Variable } & \multicolumn{2}{|c|}{ Cohort 1950-1964 } & \multicolumn{2}{|c|}{ Cohort 1965-1979 } \\
\hline & Mean & Std.dev. & Mean & Std.dev. \\
\hline \multicolumn{5}{|c|}{ Main Variables } \\
\hline \multicolumn{5}{|c|}{ Maximal education of parents } \\
\hline Other & .080 & .271 & .042 & .202 \\
\hline Vocational training, no Abitur & .733 & .442 & .717 & .450 \\
\hline Abitur (and possibly vocational training) & .071 & .257 & .069 & .255 \\
\hline Tertiary education degree & .114 & .318 & .169 & .375 \\
\hline \multicolumn{5}{|c|}{ Maximal occupational status of parents } \\
\hline Low & .431 & .495 & .334 & .471 \\
\hline Medium & .399 & .489 & .436 & .496 \\
\hline High & .168 & .374 & .229 & .420 \\
\hline \multicolumn{5}{|c|}{ Family related variables } \\
\hline Gender & .522 & .499 & .515 & .499 \\
\hline Broken family & .082 & .275 & .099 & .299 \\
\hline Number of siblings & 2.063 & 1.735 & 1.647 & 1.408 \\
\hline Migration status & .055 & .229 & .078 & .268 \\
\hline \multicolumn{5}{|c|}{ Maximal parental expectations } \\
\hline About learning & - & - & .087 & .282 \\
\hline About career & - & - & .087 & .280 \\
\hline \multicolumn{5}{|c|}{ Control variables } \\
\hline \multicolumn{5}{|c|}{ Information on previous transitions } \\
\hline \multicolumn{5}{|l|}{ (among others ...) } \\
\hline Sonder-/Förderschule & .008 & .089 & .013 & .115 \\
\hline Gesamt/Waldorfschule & .018 & .133 & .064 & .245 \\
\hline School upward mobility & .259 & .438 & .268 & .443 \\
\hline School downward mobility & .048 & .213 & .060 & .238 \\
\hline \multicolumn{5}{|c|}{ Ability indicators } \\
\hline Grade point average: very good & .020 & .142 & .038 & .192 \\
\hline Grade point average: good & .245 & .430 & .355 & .478 \\
\hline Grade retention at grade 1 to 4 & .020 & .142 & .048 & .214 \\
\hline Grade retention at grade 5 to $x$ & .170 & .376 & .164 & .371 \\
\hline \multicolumn{5}{|c|}{ Background variables } \\
\hline Region: North & .230 & .421 & .220 & .414 \\
\hline Region: West & .297 & .457 & .268 & .443 \\
\hline Region: Middle & .169 & .375 & .185 & .388 \\
\hline Region: South & .302 & .459 & .325 & .468 \\
\hline Deviation unemployment rate $(\%)$ & -.153 & 1.214 & .292 & 1.373 \\
\hline \multicolumn{5}{|c|}{ Node instruments } \\
\hline Born before school year cutoff & .322 & .467 & .268 & .443 \\
\hline Share of pupils by federal state going to HS (\%) & 55.263 & 11.189 & 39.439 & 8.268 \\
\hline Share of pupils by federal state going to RS (\%) & 20.922 & 6.767 & 29.335 & 4.883 \\
\hline Share of pupils by federal state going to GY (\%) & 23.813 & 5.452 & 31.225 & 5.679 \\
\hline Ratio students/individuals 20-22y (\%) & 34.546 & 6.596 & 60.330 & 16.953 \\
\hline Observations & & 31 & & 73 \\
\hline
\end{tabular}


Table 2 - Average partial probability effects: parental education

\begin{tabular}{|c|c|c|c|c|c|c|}
\hline \multirow{3}{*}{ Transition } & \multicolumn{3}{|c|}{ Cohort 1950-1964 } & \multicolumn{3}{|c|}{ Cohort 1965-1979 } \\
\hline & \multicolumn{3}{|c|}{ Parental education $^{a}$} & \multicolumn{3}{|c|}{ Parental education $^{a}$} \\
\hline & Voc/no Abi & Abi & Uni/FH & Voc/no Abi & Abi & Uni/FH \\
\hline $\begin{array}{l}\text { Kindergarten-Yes } \\
\text { (vs Kindergarten-No) }\end{array}$ & $\begin{array}{c}.004 \\
(.029)\end{array}$ & $\begin{array}{c}.034 \\
(.040)\end{array}$ & $\begin{array}{l}.097^{* *} \\
(.041)\end{array}$ & $\begin{array}{l}.079 * \\
(.041)\end{array}$ & $\begin{array}{l}.129 * * * \\
(.050)\end{array}$ & $\begin{array}{l}.137^{* * *} \\
(.046)\end{array}$ \\
\hline Grundschule-Hauptschule & $\begin{array}{l}-.053^{*} \\
(.028)\end{array}$ & $\begin{array}{c}-.250^{* * *} \\
(.040)\end{array}$ & $\begin{array}{c}-.311^{* * *} \\
(.037)\end{array}$ & $\begin{array}{l}-.082 \\
(.050)\end{array}$ & $\begin{array}{c}-.208^{* * *} \\
(.060)\end{array}$ & $\begin{array}{c}-.241^{* * *} \\
(.054)\end{array}$ \\
\hline Grundschule-Realschule & $\begin{array}{l}.054^{*} \\
(.029)\end{array}$ & $\begin{array}{l}.003 \\
(.041)\end{array}$ & $\begin{array}{l}-.059 \\
(.039)\end{array}$ & $\begin{array}{c}.091 \\
(.056)\end{array}$ & $\begin{array}{c}.031 \\
(.069)\end{array}$ & $\begin{array}{c}-.153^{* * *} \\
(.059)\end{array}$ \\
\hline Grundschule-Gymnasium & $\begin{array}{l}-.001 \\
(.030) \\
\end{array}$ & $\begin{array}{l}.247^{* * *} \\
(.044)\end{array}$ & $\begin{array}{l}.371^{* * *} \\
(.043) \\
\end{array}$ & $\begin{array}{l}-.008 \\
(.059) \\
\end{array}$ & $\begin{array}{l}.177^{* *} \\
(.070) \\
\end{array}$ & $\begin{array}{l}.395^{* * *} \\
(.066)\end{array}$ \\
\hline Hauptschule degree-Up & .010 & $.182^{*}$ & $.261^{* *}$ & .110 & .154 & $.284^{* *}$ \\
\hline (vs Hauptschule degree-Vocational training) & $(.039)$ & $(.100)$ & $(.104)$ & $(.068)$ & $(.112)$ & $(.130)$ \\
\hline Realschule-Realschule degree & .014 & .005 & .011 & .022 & .004 & .002 \\
\hline (vs Realschule-Realschule dropout) & $(.022)$ & $(.032)$ & $(.030)$ & $(.029)$ & $(.045)$ & $(.047)$ \\
\hline Realschule degree-Up & .014 & .060 & $.213^{* * *}$ & .104 & $.230^{* *}$ & $.322^{* * *}$ \\
\hline (vs Realschule degree-Vocational training) & $(.048)$ & $(.069)$ & $(.075)$ & $(.075)$ & $(.093)$ & $(.095)$ \\
\hline Gymnasium-Gymnasium degree & .005 & .037 & -.003 & -.015 & -.014 & .014 \\
\hline (vs Gymnasium-Gymnasium dropout) & $(.033)$ & $(.037)$ & $(.038)$ & $(.073)$ & $(.075)$ & $(.075)$ \\
\hline Gymnasium degree-Study & .096 & .078 & $.139^{*}$ & -.097 & -.153 & .030 \\
\hline (vs Gymnasium degree-Vocational training) & $(.067)$ & $(.076)$ & $(.075)$ & $(.107)$ & $(.120)$ & $(.112)$ \\
\hline Vocational training-Vocational training degree & .015 & -.024 & .010 & .014 & .018 & -.028 \\
\hline (vs Vocational training-Vocational training dropout) & $(.014)$ & $(.031)$ & $(.026)$ & $(.023)$ & $(.038)$ & $(.032)$ \\
\hline Vocational training degree-Terminal & .007 & .005 & -.024 & -.057 & -.086 & $-.111^{*}$ \\
\hline & $(.027)$ & $(.043)$ & $(.043)$ & $(.050)$ & $(.064)$ & $(.063)$ \\
\hline Vocational training degree-Master Craftsman & .009 & .002 & -.024 & $.056^{*}$ & .049 & .059 \\
\hline & $(.019)$ & $(.033)$ & $(.031)$ & $(.029)$ & $(.040)$ & $(.040)$ \\
\hline Vocational training degree-Study & -.017 & -.007 & .048 & .001 & .037 & .052 \\
\hline & $(.022)$ & $(.034)$ & $(.035)$ & $(.046)$ & $(.055)$ & $(.056)$ \\
\hline Study-University & $-b$ & $-b$ & $-b$ & $-.232^{* * *}$ & $-.238^{* *}$ & -.091 \\
\hline (vs Study-FH) & & & & $(.080)$ & $(.095)$ & $(.085)$ \\
\hline Uni/FH degree & -.023 & -.093 & -.030 & .144 & .078 & .082 \\
\hline (vs Uni/FH dropout) & $(.052)$ & $(.062)$ & $(.059)$ & $(.110)$ & $(.123)$ & $(.115)$ \\
\hline Uni/FH dropout-Terminal & .235 & .187 & .145 & $-.360^{* *}$ & -.093 & $-.271^{*}$ \\
\hline (vs Uni/FH dropout-Vocational training) & $(.210)$ & $(.223)$ & $(.221)$ & $(.157)$ & $(.175)$ & $(.160)$ \\
\hline $\begin{array}{l}\text { Master Craftsman degree } \\
\text { (vs Master Craftsman dropout) }\end{array}$ & $\begin{array}{c}.042 \\
(.090)\end{array}$ & $-b$ & $-b$ & $\begin{array}{c}.015 \\
(.119)\end{array}$ & $\begin{array}{l}-.123 \\
(.174)\end{array}$ & - \\
\hline
\end{tabular}

Source: NEPS SC6 and own calculations.

Standard errors in parentheses.

a Maximum value of father/mother

${ }^{b}$ No estimate possible for cohort 1950-1964

$* * * / * * / *$ statistically significant at $1 \% / 5 \% / 10 \%$-level. 
Table 3 - Average partial probability effects: parental occupational status

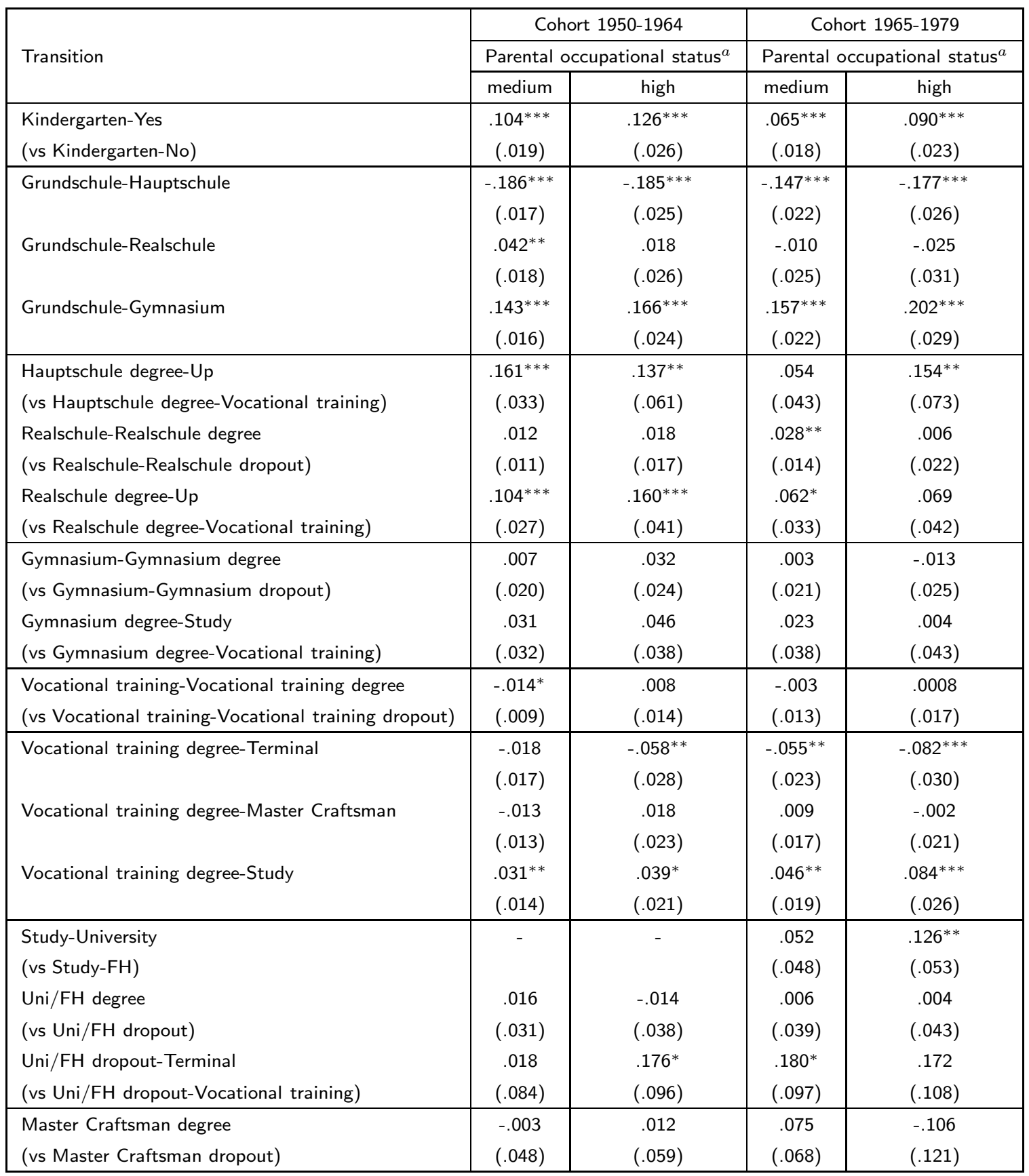

Source: NEPS SC6 and own calculations.

Standard errors in parentheses.

${ }^{a}$ Maximum value of father/mother

$* * * / * * / *$ statistically significant at $1 \% / 5 \% / 10 \%$-level. 
Table 4 - Average partial probability effects: gender and number of siblings

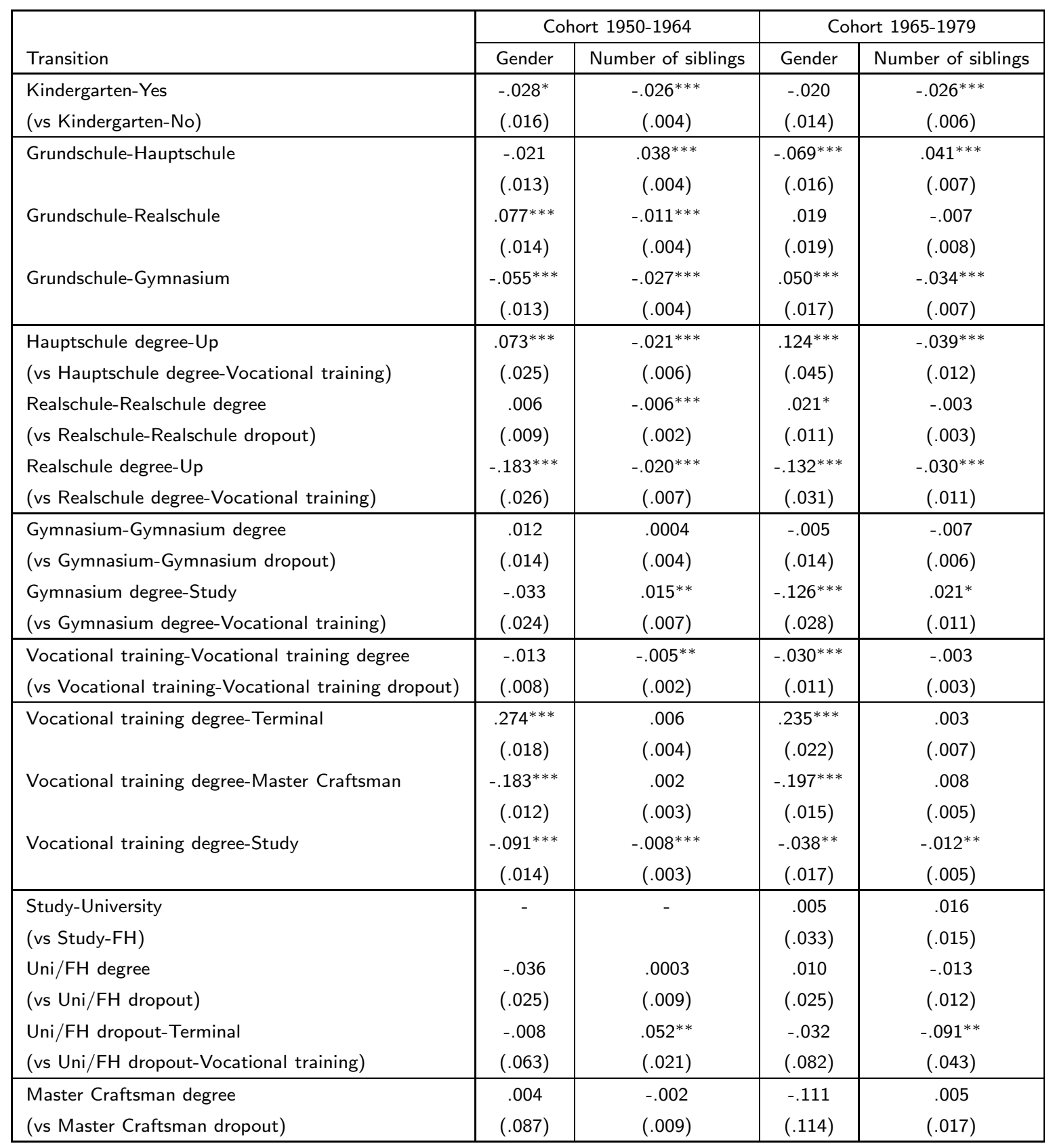

Source: NEPS SC6 and own calculations.

Standard errors in parentheses.

$* * * /{ }^{* *} /{ }^{*}$ statistically significant at $1 \% / 5 \% / 10 \%$-level. 
Table 5 - Average partial probability effects: broken family and migration status

\begin{tabular}{|c|c|c|c|c|}
\hline \multirow[b]{2}{*}{ Transition } & \multicolumn{2}{|c|}{ Cohort 1950-1964 } & \multicolumn{2}{|c|}{ Cohort 1965-1979 } \\
\hline & Broken family & Migration status & Broken family & Migration status \\
\hline $\begin{array}{l}\text { Kindergarten-Yes } \\
\text { (vs Kindergarten-No) }\end{array}$ & $\begin{array}{c}.033 \\
(.029)\end{array}$ & $\begin{array}{c}.012 \\
(.033)\end{array}$ & $\begin{array}{l}-.011 \\
(.023)\end{array}$ & $\begin{array}{l}-.049 \\
(.034)\end{array}$ \\
\hline Grundschule-Hauptschule & $\begin{array}{l}.082^{* * *} \\
(.026)\end{array}$ & $\begin{array}{l}-.011 \\
(.033)\end{array}$ & $\begin{array}{l}.097^{* * *} \\
(.028)\end{array}$ & $\begin{array}{c}.008 \\
(.032)\end{array}$ \\
\hline Grundschule-Realschule & $\begin{array}{l}-.039 \\
(.027)\end{array}$ & $\begin{array}{l}-.004 \\
(.034)\end{array}$ & $\begin{array}{l}-.007 \\
(.031)\end{array}$ & $\begin{array}{c}.018 \\
(.038)\end{array}$ \\
\hline Grundschule-Gymnasium & $\begin{array}{l}-.042^{*} \\
(.024)\end{array}$ & $\begin{array}{c}.015 \\
(.028)\end{array}$ & $\begin{array}{c}-.090^{* * *} \\
(.025)\end{array}$ & $\begin{array}{l}-.026 \\
(.032)\end{array}$ \\
\hline $\begin{array}{l}\text { Hauptschule degree-Up } \\
\text { (vs Hauptschule degree-Vocational training) } \\
\text { Realschule-Realschule degree } \\
\text { (vs Realschule-Realschule dropout) } \\
\text { Realschule degree-Up } \\
\text { (vs Realschule degree-Vocational training) }\end{array}$ & $\begin{array}{c}-.093^{* *} \\
(.038) \\
-.045^{*} \\
(.025) \\
.012 \\
(.046)\end{array}$ & $\begin{array}{l}.015 \\
(.052) \\
.001 \\
(.016) \\
.139^{* *} \\
(.059)\end{array}$ & $\begin{array}{c}-.040 \\
(.059) \\
-.001 \\
(.019) \\
.039 \\
(.045)\end{array}$ & $\begin{array}{c}.111 \\
(.080) \\
-.079^{* *} \\
(.035) \\
.014 \\
(.059)\end{array}$ \\
\hline $\begin{array}{l}\text { Gymnasium-Gymnasium degree } \\
\text { (vs Gymnasium-Gymnasium dropout) } \\
\text { Gymnasium degree-Study } \\
\text { (vs Gymnasium degree-Vocational training) }\end{array}$ & $\begin{array}{c}-.126^{* * *} \\
(.037) \\
.067 \\
(.046)\end{array}$ & $\begin{array}{l}.033 \\
(.024) \\
-.055 \\
(.050)\end{array}$ & $\begin{array}{l}-.019 \\
(.023) \\
-.027 \\
(.043)\end{array}$ & $\begin{array}{l}-.060 \\
(.038) \\
.128^{* *} \\
(.060)\end{array}$ \\
\hline $\begin{array}{l}\text { Vocational training-Vocational training degree } \\
\text { (vs Vocational training-Vocational training dropout) } \\
\text { Vocational training degree-Terminal }\end{array}$ & $\begin{array}{c}-.084^{* * *} \\
(.022) \\
.051^{* *} \\
(.026)\end{array}$ & $\begin{array}{c}-.026 \\
(.019) \\
-.084^{* *} \\
(.038)\end{array}$ & $\begin{array}{l}-.017 \\
(.020) \\
.060^{*} \\
(.033)\end{array}$ & $\begin{array}{c}-.017 \\
(.026) \\
.018 \\
(.043)\end{array}$ \\
\hline Vocational training degree-Master Craftsman & $\begin{array}{l}-.027 \\
(.020)\end{array}$ & $\begin{array}{l}.048^{*} \\
(.031)\end{array}$ & $\begin{array}{c}-.049^{* *} \\
(.022)\end{array}$ & $\begin{array}{l}-.023 \\
(.027)\end{array}$ \\
\hline Vocational training degree-Study & $\begin{array}{l}-.023 \\
(.020)\end{array}$ & $\begin{array}{c}.035 \\
(.030)\end{array}$ & $\begin{array}{l}-.011 \\
(.028)\end{array}$ & $\begin{array}{c}.004 \\
(.037)\end{array}$ \\
\hline $\begin{array}{l}\text { Study-University } \\
\text { (vs Study-FH) } \\
\text { Uni/FH degree } \\
\text { (vs Uni/FH dropout) } \\
\text { Uni/FH dropout-Terminal } \\
\text { (vs Uni/FH dropout-Vocational training) }\end{array}$ & $\begin{array}{c}- \\
-.036 \\
(.046) \\
-.123 \\
(.156)\end{array}$ & $\begin{array}{c}- \\
.056 \\
(.039) \\
.238^{* *} \\
(.107)\end{array}$ & $\begin{array}{c}-.007 \\
(.056) \\
-.105^{* *} \\
(.052) \\
.119 \\
(.075)\end{array}$ & $\begin{array}{c}.040 \\
(.068) \\
.017 \\
(.047) \\
.137 \\
(.124)\end{array}$ \\
\hline $\begin{array}{l}\text { Master Craftsman degree } \\
\text { (vs Master Craftsman dropout) }\end{array}$ & $\begin{array}{l}-.034 \\
(.089)\end{array}$ & $\begin{array}{l}-.019 \\
(.076)\end{array}$ & $\begin{array}{c}.033 \\
(.069)\end{array}$ & $\begin{array}{l}-.171 \\
(.143)\end{array}$ \\
\hline
\end{tabular}

Source: NEPS SC6 and own calculations.

Standard errors in parentheses.

$* * * / * * / *$ statistically significant at $1 \% / 5 \% / 10 \%$-level. 
Table 6 - Average partial probability effects: parental expectations and random effect

\begin{tabular}{|c|c|c|c|c|c|}
\hline \multirow[b]{2}{*}{ Transition } & \multicolumn{2}{|c|}{ Cohort 1950-1964 } & \multicolumn{3}{|c|}{ Cohort 1965-1979 } \\
\hline & $\begin{array}{c}\text { Parental }^{a} \\
\text { expectations } \\
\text { learning/career }\end{array}$ & $\begin{array}{c}\text { Random } \\
\text { effect }\end{array}$ & $\begin{array}{l}\text { Parental }^{b} \\
\text { expectations } \\
\text { learning }\end{array}$ & $\begin{array}{l}\text { Parental } \\
\text { expectations } \\
\text { career }\end{array}$ & $\begin{array}{l}\text { Random } \\
\text { effect }\end{array}$ \\
\hline $\begin{array}{l}\text { Kindergarten-Yes } \\
\text { (vs Kindergarten-No) }\end{array}$ & - & $\begin{array}{l}-.002 \\
(.018)\end{array}$ & $\begin{array}{c}.055 \\
(.034)\end{array}$ & $\begin{array}{c}.002 \\
(.035)\end{array}$ & $\begin{array}{c}.021 \\
(.020)\end{array}$ \\
\hline Grundschule-Hauptschule & - & $\begin{array}{c}-.101^{* * *} \\
(.014)\end{array}$ & $\begin{array}{c}.037 \\
(.032)\end{array}$ & $\begin{array}{c}.016 \\
(.035)\end{array}$ & $\begin{array}{c}-.106^{* * *} \\
(.025)\end{array}$ \\
\hline Grundschule-Realschule & - & $\begin{array}{l}.112^{* * *} \\
(.017)\end{array}$ & $\begin{array}{c}.009 \\
(.036)\end{array}$ & $\begin{array}{c}-.080^{* *} \\
(.039)\end{array}$ & $\begin{array}{l}.091^{* * *} \\
(.021)\end{array}$ \\
\hline Grundschule-Gymnasium & - & $\begin{array}{l}-.011 \\
(.016)\end{array}$ & $\begin{array}{l}-.047 \\
(.031)\end{array}$ & $\begin{array}{l}.064^{* *} \\
(.032)\end{array}$ & $\begin{array}{c}.014 \\
(.022)\end{array}$ \\
\hline $\begin{array}{l}\text { Hauptschule degree-Up } \\
\text { (vs Hauptschule degree-Vocational training) }\end{array}$ & - & $\begin{array}{l}.359^{* * *} \\
(.024)\end{array}$ & $\begin{array}{c}.062 \\
(.078)\end{array}$ & $\begin{array}{l}-.029 \\
(.075)\end{array}$ & $\begin{array}{l}.252^{* * *} \\
(.009)\end{array}$ \\
\hline $\begin{array}{l}\text { Realschule-Realschule degree } \\
\text { (vs Realschule-Realschule dropout) }\end{array}$ & - & $\begin{array}{c}.020^{* * *} \\
(.003)\end{array}$ & $\begin{array}{l}.011 \\
(.042)\end{array}$ & $\begin{array}{l}-.036 \\
(.037)\end{array}$ & $\begin{array}{c}.028 \\
(.022)\end{array}$ \\
\hline $\begin{array}{l}\text { Realschule degree-Up } \\
\text { (vs Realschule degree-Vocational training) }\end{array}$ & - & $\begin{array}{l}.370^{* * *} \\
(.023)\end{array}$ & $\begin{array}{l}-.055 \\
(.057)\end{array}$ & $\begin{array}{l}.111^{*} \\
(.062)\end{array}$ & $\begin{array}{l}204^{* * *} \\
(.033)\end{array}$ \\
\hline $\begin{array}{l}\text { Gymnasium-Gymnasium degree } \\
\text { (vs Gymnasium-Gymnasium dropout) } \\
\text { Gymnasium degree-Study } \\
\text { (vs Gymnasium degree-Vocational training) }\end{array}$ & - & $\begin{array}{c}-.007 \\
(.024) \\
-.254^{* * *} \\
(.023)\end{array}$ & $\begin{array}{c}-.007 \\
(.036) \\
.020 \\
(.045)\end{array}$ & $\begin{array}{c}-.130 * * * \\
(.030) \\
.040 \\
(.051)\end{array}$ & $\begin{array}{c}-.024^{*} \\
(.013) \\
-.294^{* * *} \\
(.020)\end{array}$ \\
\hline $\begin{array}{l}\text { Vocational training-Vocational training degree } \\
\text { (vs Vocational training-Vocational training dropout) }\end{array}$ & - & $\begin{array}{l}.007^{*} \\
(.004)\end{array}$ & $\begin{array}{l}-.007 \\
(.015)\end{array}$ & $\begin{array}{l}-.017 \\
(.015)\end{array}$ & $\begin{array}{l}-.013 \\
(.028) \\
\end{array}$ \\
\hline Vocational training degree-Terminal & - & $\begin{array}{c}-.194^{* * *} \\
(.015)\end{array}$ & $\begin{array}{c}.019 \\
(.040)\end{array}$ & $\begin{array}{l}-.051 \\
(.040)\end{array}$ & $\begin{array}{c}-.135^{* * *} \\
(.015)\end{array}$ \\
\hline Vocational training degree-Master Craftsman & - & $\begin{array}{l}-.011 \\
(.008)\end{array}$ & $\begin{array}{c}.008 \\
(.028)\end{array}$ & $\begin{array}{c}.034 \\
(.027)\end{array}$ & $\begin{array}{l}.007 \\
(.011)\end{array}$ \\
\hline Vocational training degree-Study & - & $\begin{array}{l}.205^{* * *} \\
(.015) \\
\end{array}$ & $\begin{array}{l}-.028 \\
(.033) \\
\end{array}$ & $\begin{array}{c}.016 \\
(.033) \\
\end{array}$ & $\begin{array}{l}.127^{* * *} \\
(.008)\end{array}$ \\
\hline $\begin{array}{l}\text { Study-University } \\
\text { (vs Study-FH) }\end{array}$ & - & $-{ }^{a}$ & $\begin{array}{r}-.108^{* *} \\
(.050)\end{array}$ & $\begin{array}{c}.030 \\
(.056)\end{array}$ & $\begin{array}{c}-.195^{* * *} \\
(.047)\end{array}$ \\
\hline $\begin{array}{l}\text { Uni/FH degree } \\
\text { (vs Uni/FH dropout) }\end{array}$ & - & $\begin{array}{l}.009 \\
(.046)\end{array}$ & $\begin{array}{l}-.079^{*} \\
(.041)\end{array}$ & $\begin{array}{l}-.018 \\
(.042)\end{array}$ & $\begin{array}{l}-.204^{*} \\
(.111)\end{array}$ \\
\hline $\begin{array}{l}\text { Uni/FH dropout-Terminal } \\
\text { (vs Uni/FH dropout-Vocational training) }\end{array}$ & - & $\begin{array}{l}-.010 \\
(.077)\end{array}$ & $\begin{array}{l}-.084 \\
(.103)\end{array}$ & $\begin{array}{l}-.037 \\
(.118)\end{array}$ & $\begin{array}{c}.046 \\
(.085)\end{array}$ \\
\hline $\begin{array}{l}\text { Master Craftsman degree } \\
\text { (vs Master Craftsman dropout) }\end{array}$ & - & $\begin{array}{c}.026 \\
(.024)\end{array}$ & $\begin{array}{l}-.051 \\
(.078)\end{array}$ & $\begin{array}{c}.183 \\
(.129)\end{array}$ & $\begin{array}{c}-.069^{* *} \\
(.030)\end{array}$ \\
\hline
\end{tabular}

Source: NEPS SC6 and own calculations.

Standard errors in parentheses.

a Not available for cohort 1950-1964

$b$ Maximum value of father/mother

$* * * / * * / *$ statistically significant at $1 \% / 5 \% / 10 \%$-level. 
9 Figures

- (Intentionally left blank) - 


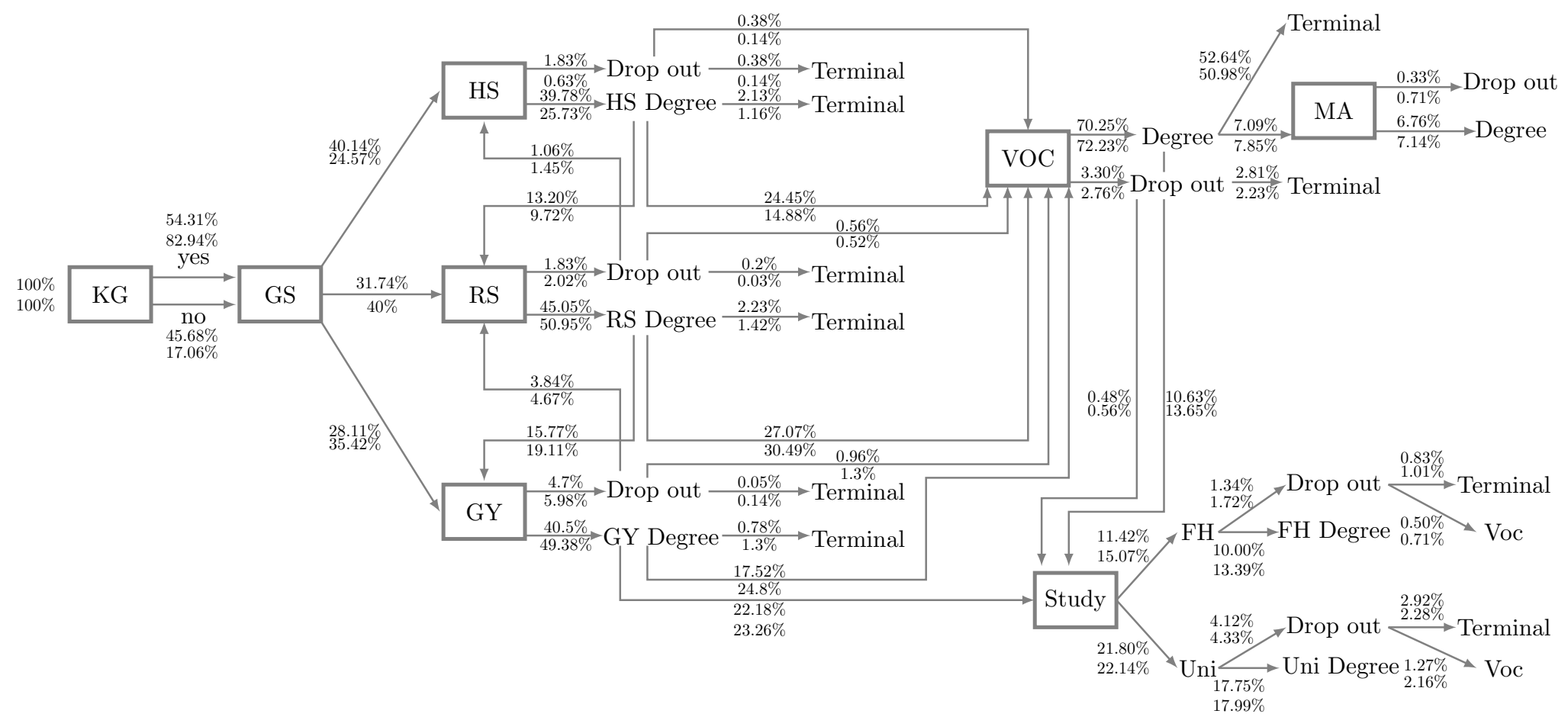

Figure 1 - German education system (upper numbers: percentages of birth cohort 1950-1964,

lower numbers: percentages of birth cohort 1965-1979) 
Figure 2 - Random effects distribution-all individuals

(a) Cohort 1950-1964

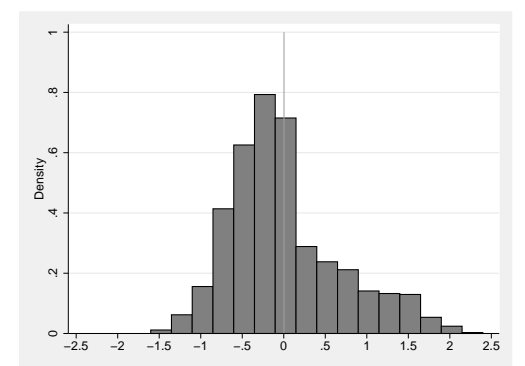

(b) Cohort 1965-1979

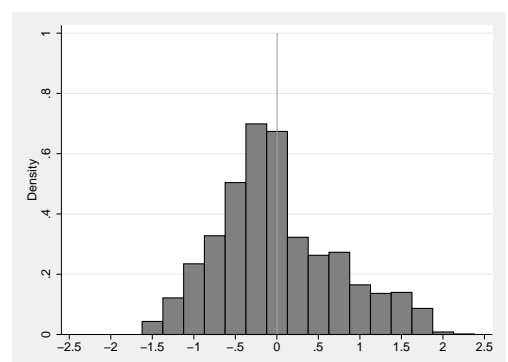

Figure 3 - Random effects distribution-Hauptschule degree

(a) Cohort 1950-1964

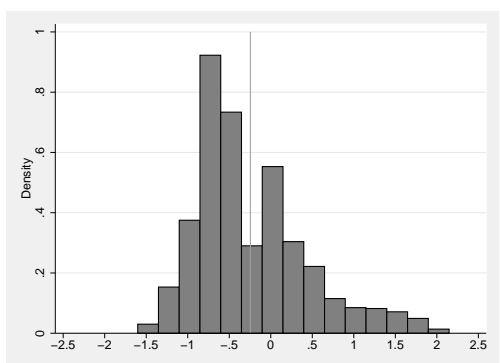

(b) Cohort 1965-1979

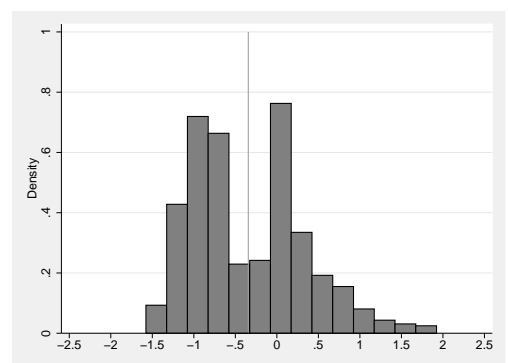

Figure 4 - Random effects distribution-Realschule

(a) Cohort 1950-1964

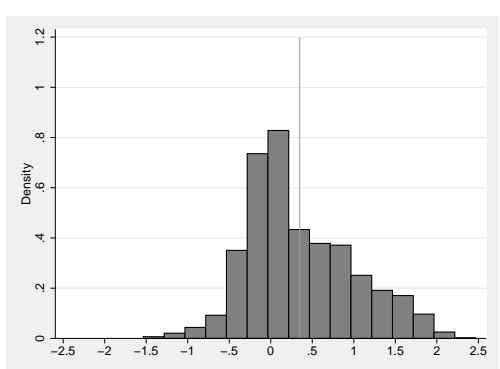

(b) Cohort 1965-1979

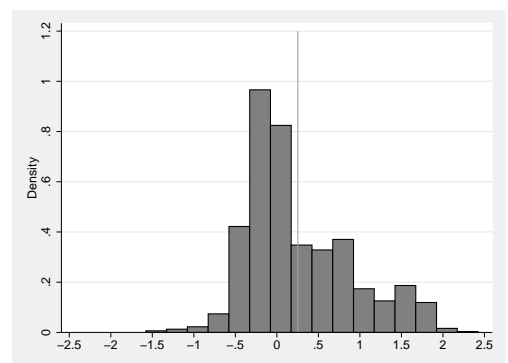


Figure 5 - Random effects distribution-Realschule degree

(a) Cohort 1950-1964

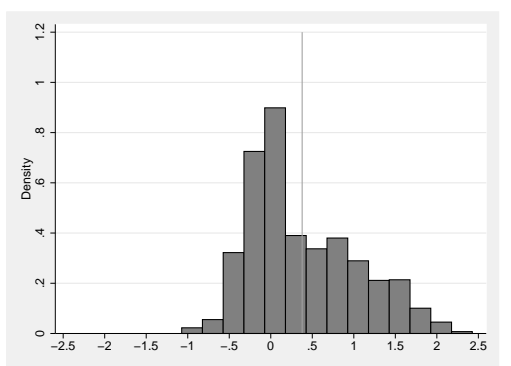

(b) Cohort 1965-1979

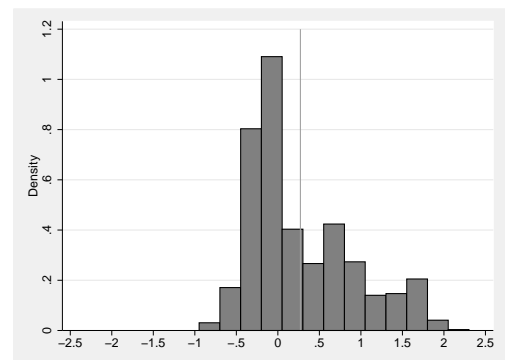

Figure 6 - Random effects distribution-Gymnasium

(a) Cohort 1950-1964

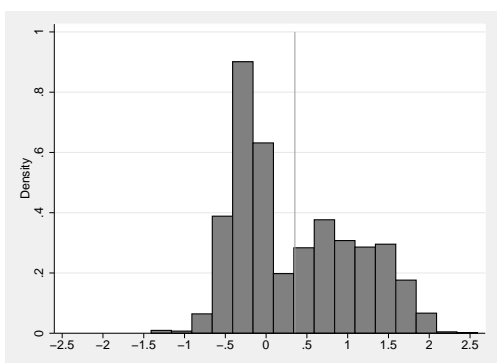

(b) Cohort 1965-1979

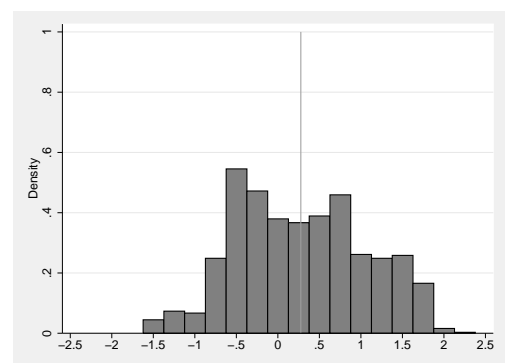

Figure 7 - Random effects distribution-Gymnasium degree

(a) Cohort 1950-1964

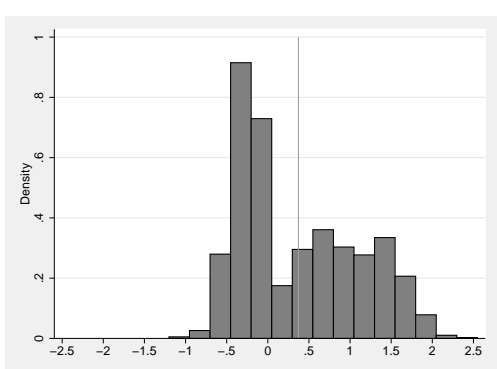

(b) Cohort 1965-1979

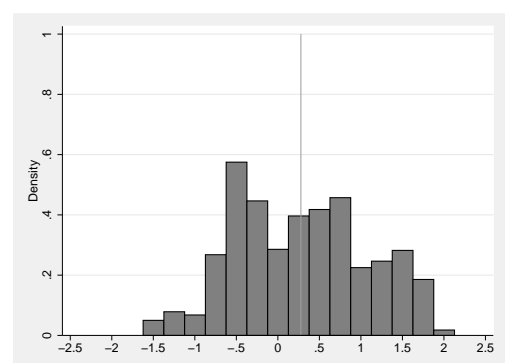


Figure 8 - Random effects distribution-Vocational training

(a) Cohort 1950-1964

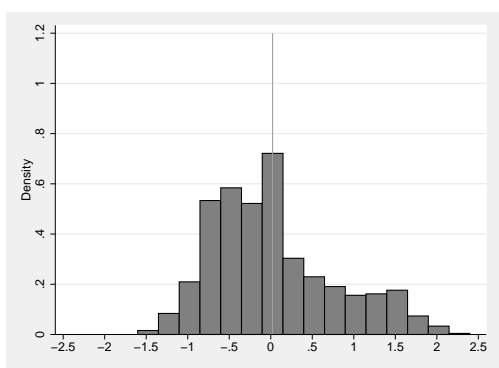

(b) Cohort 1965-1979

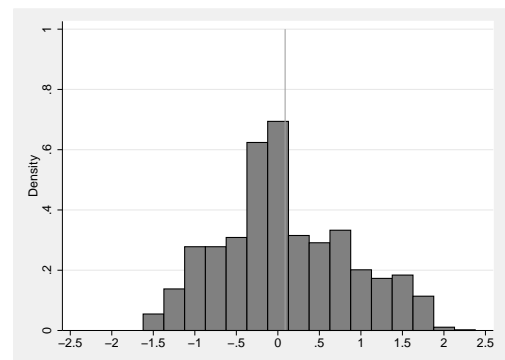

Figure 9 - Random effects distribution-Vocational training degree

(a) Cohort 1950-1964

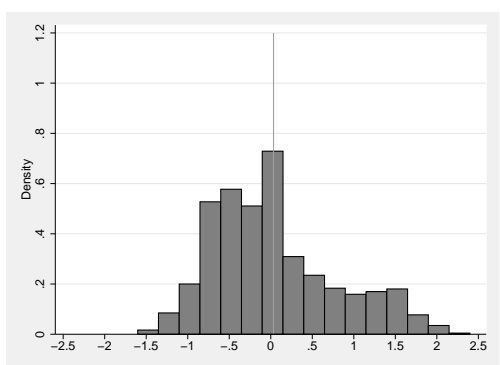

(b) Cohort 1965-1979

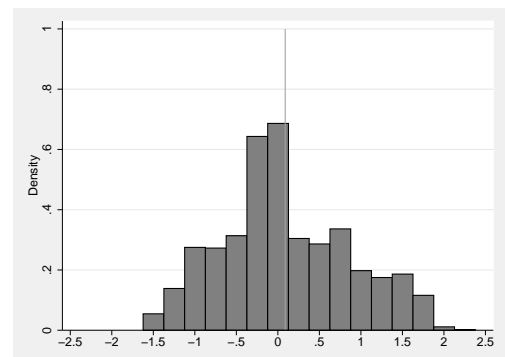

Figure 10 - Random effects distribution-Study

(a) Cohort 1950-1964

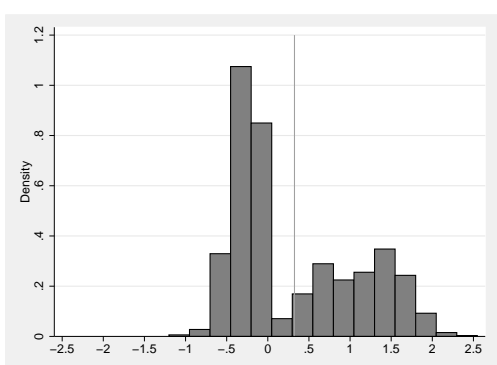

(b) Cohort 1965-1979

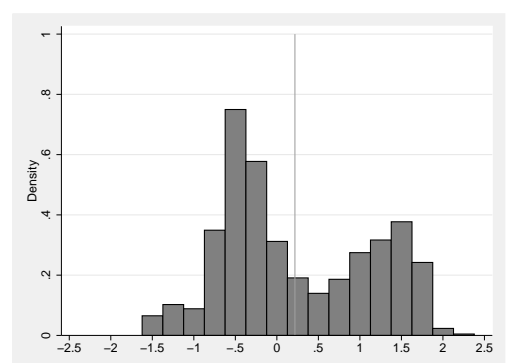


Figure 11 - Random effects distribution-Study indirectly

(a) Cohort 1950-1964

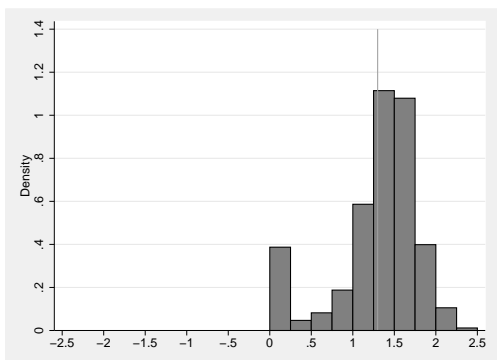

(b) Cohort 1965-1979

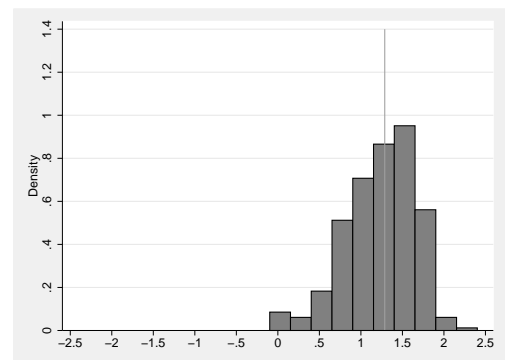

Figure 12 - Random effects distribution-University/FH degree

(a) Cohort 1950-1964

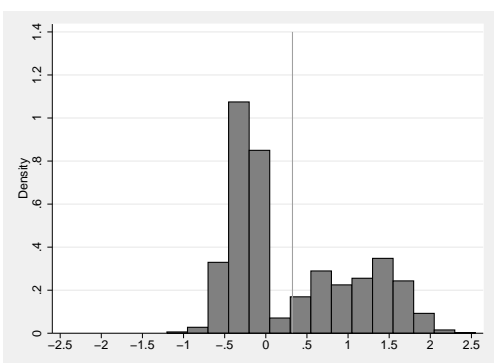

(b) Cohort 1965-1979

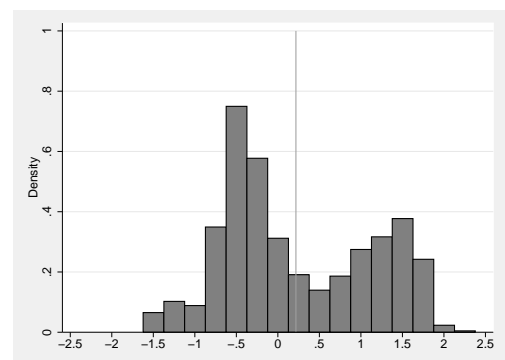

Figure 13 - Random effects distribution-University/FH dropout

(a) Cohort 1950-1964

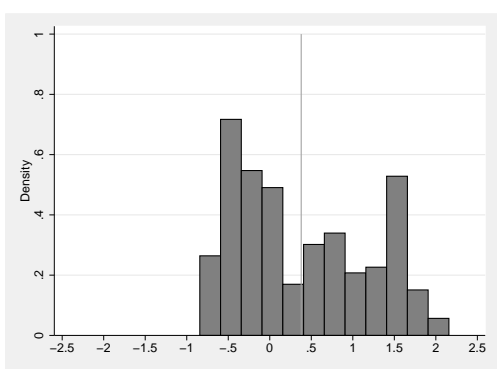

(b) Cohort 1965-1979

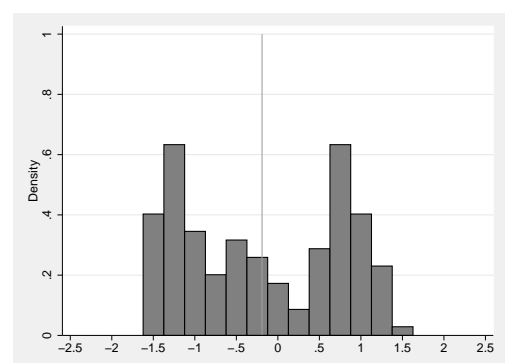


Figure 14 - Random effects distribution-Master craftsman

(a) Cohort 1950-1964

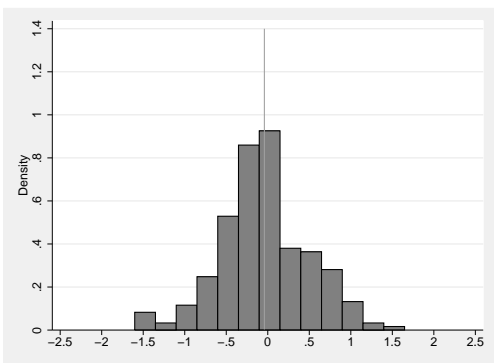

(b) Cohort 1965-1979

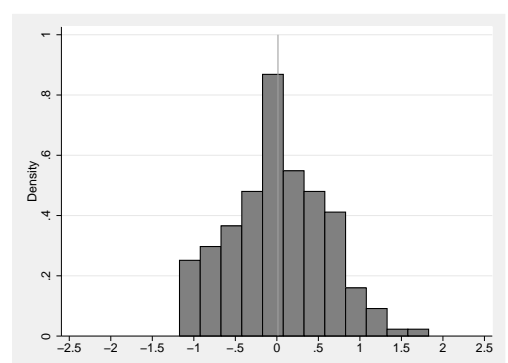

